\title{
JUHO SANKAMO
}

\section{Jesus' Entry into Jerusalem}

$\mathrm{T}$ his article intends to contribute to the understanding of Jesus' entry into Jerusalem. The author studies the entry, which is found in all the Gospels, in its Jewish context. The author argues that Jesus' entry into Jerusalem on an ass is to be understood as a prophetic sign which was primarily meant to convey a message to the Jews.

\section{Introduction}

In this article I intend to argue that Jesus' entry into Jerusalem on an ass is to be understood as a symbolic act which was primarily meant to convey a message to the Jews. The symbolic meaning of Jesus' entry into Jerusalem is strongly dependent on the context of Passover and Jerusalem, and on the enigmatic significance of the ass. In the scholarly discussion Jesus' entry on an ass has sometimes been seen as provocative of a political and religious conflict with the Jewish and Roman aristocracy of Jerusalem. It seems to me that in his entry Jesus intentionally refrained from the use of the most self-evident and popular royal symbols - that is to say he did not wear a diadem or a purple coat. Instead he entered the city on an ass, which for the religious Jews recalled the biblical narratives of a king arriving into Jerusalem (1 Kgs. 1; Zech. 9). At least for some attentive and religious Jews, Jesus' entry on an ass signalled a message of peace and humility, but also of power and royalty. The ass, however, rendered Jesus' entry quite enigmatic. The non-Jews would not have regarded it as provocative. Some of the Jews would have understood it as a prophetic symbol with royal overtones. However, as the entry signalled a message of peace and humility, it did not in itself incite the disciples to a zealous revolt against anyone.

As a clarification, in this article I will use the term 'Romans' as I refer to the Roman troops - that is the cohort stationed in Jerusalem during the pilgrimage feasts (Bell. 2:224; Ant. 20:106-107) - and to the Roman political aristocracy. It is worth pointing out that during the 30 os CE the 'Roman soldiers' in Palestine were regularly not Italian - and not Jewish for that matter (cf. Ant. 14:204, 226-8, 232). The Roman cohorts in Palestine consisted of non-Jewish soldiers who had been gathered from nearby areas. Consequently these so-called 'Roman' soldiers in Palestine were mostly Samaritans, Phoenicians, and Tyrians (Sankamo 2012a: 154-6; see also Kinman 2005: 253). ${ }^{1}$

\section{Evaluating the historical value of Mark 11:1-11 and John 12:12-19}

All the Gospels transmit the account of Jesus riding into Jerusalem on an ass some days before the Passover. Moreover, all the Gospels place the event chronologically at the end of Jesus' life. Matthew (21:1-9) and Luke (19:28-38) are relying on the tradition found in Mark 11:1-11. John (12:12-19) differs from Mark to the extent that it is possible that he knew the story from another, separate source. If so, then our knowledge of Jesus' entry is based on two dif-

1 During the time of Jesus there was only a very limited number of permanent Roman troops, perhaps 3,000 soldiers, stationed in all of Palestine. These Roman troops were in Caesarea Maritima, Jericho, Jerusalem and in Ashkelon. See Chancey 2005: 47-9; Stegemann 2011: 2296-7. When revolts occurred and more Roman soldiers were needed to secure peace in Jewish Palestine, the Roman troops had to come from Syria. Three to four Roman legions - that is about 20,000 soldiers - were stationed in Syria (Stegemann 2011: 2297). 
ferent and independent traditions: Mark's and John's (Kinman 2005: 227-8; Tan 1997: 137-8; Fredriksen 1999: 143, 233-4; Meier 2001: 54-5; Tatum 1998: $136-8) .^{2}$ In this case the criterion of multiple attestations supports the claim that the story of Jesus' entry into Jerusalem on an ass is grounded in actual history (see Kinman 2005: 227-9).

The similarities shared by the Synoptics and John are as follows: Jesus entered Jerusalem riding on an ass some days prior to the Passover. He was accompanied by crowds who sang Hosanna. Both Mark and John refer more or less implicitly to the prophecy of Zech. 9:9, but both of them fail to connect the prophecy directly to Jesus' outspoken intentions. Neither Mark nor John state that Jesus was arrested immediately on entering the city. The entrance in Mark 11:111, followed by Luke and Matthew, is divided into two parts: Jesus first sends two disciples to a nearby village to collect an ass for him from there (11:1-6). After this he receives the ass from the disciples and rides into Jerusalem (11:7-11). Curiously John has not preserved the first part of the Synoptic version.

Perhaps the majority of scholars regard Jesus' riding on an ass into Jerusalem as principally historical (Kinman 2005: 235, 257-60; Meier 2001: 54-5; Tatum 1998: 129-30; Laaksonen 2002: 324-5, 32930; Tan 1997: 138-9). ${ }^{3}$ The skepticism against the

2 The clear differences between Mark and John are as follows: John knows nothing of the two men sent to bring the ass. In the Synoptics Jesus is said to have healed a blind man, or two blind men, in Bethany just before his royal entry (Mark 10:46-52; Luke 18:3543; Matt 20:29-34). In the Synoptics it is emphasized that the blind men see that Jesus is the 'Son of David'. Also John claims that Jesus visited Bethany just before he arrived into Jerusalem, but in John's Gospel Jesus is anointed there (John 12:1-11). Mark and John use a different word for the ass. In John the disciples do not put garments on the ass. In John's account it is underlined that people followed Jesus into Jerusalem - Jesus had gained the interest of the Jews because he had previously raised Lazarus from the dead. According to John 12:19 the whole world had gone over to Jesus. Laaksonen supports the view that John's version of the entry story is based on the Markan source (Laaksonen 2002: 322).

3 Tan mentions three reasons which are often used for supporting the authenticity of the entry: 1) Pilgrims usually did not enter Jerusalem riding on an ass, but on foot. 2) As far as we are aware Zech. 9:9 was not interpreted in a messianic way prior to Jesus. More in tune with popular expectations would have been a triumphal entry of the Messiah on a warhorse. In later historical value of the Gospel accounts of Jesus' entry is usually based on two arguments. First, Jesus' entry is interpreted as a triumphant entry which reflects more the early Christians' Christological beliefs than the historical reality of Jesus' actual entry into Jerusalem. Secondly, some scholars have claimed that if Jesus' entry was royal (and messianic), we should expect that the Romans to have arrested Jesus on the spot (See Kinman 2005: 224-7).

\section{Jesus' royal entry and the pilgrimage crowds}

Honour and shame were central concepts in ancient Mediterranean cultures. Great public figures such as kings and rulers aspired to their official arrivals being honourable. The Gospels were written and read in the first and second century Greco-Roman world which was familiar with the concept of the $\pi \alpha \rho o v \sigma^{i} \alpha$, a royal or/and celebratory entry. It has been shown by references to written sources that some general patterns for a $\pi \alpha \rho o v \sigma i \alpha$ were known throughout the Greco-Roman world, from Asia Minor to Palestine and Egypt. Attentive readers and listeners of the first century would inevitably have associated Jesus' entry with these celebratory entries (Kinman 2005: 230-2, 254).

Some examples are sufficient to show that public and celebratory entries of kings and rulers were considered crucially important. According to 2 Macc. 4:21-22 the Seleucid King Antiochus Epiphanes 'was welcomed magnificently by Jason and the city (Jerusalem), and ushered in with a blaze of torches and with shouts. The procurator Florus (64-6 CE) advises the high priest - so Josephus tells us (Bell. 2:318-24) - to request the people of Jerusalem to salute the Roman troops who were coming up from Caesarea (cf. Judith 3:7). The high priest gathered the multitudes to the temple and pleaded that, for the sake of the nation's freedom and peace, they would go out and greet the arriving Roman cohorts in a very civil manner. This account gives an example of the significance of the salutations and greetings in a triumphal entry or in a $\pi \alpha \rho o v \sigma i \alpha$. The same point is apparent in Ant. 15:405, which clarifies how thankful Vitellius, the Governor of Syria was after being received magnificently into

Rabbinic sources the idea of the Messiah entering on an ass is considered embarrassing: b. Sanh. 98a. 3) An explicit reference to Zech. 9:9 is not found in the earliest transmission of the source of Jesus' entry - i.e. from Mark 11:1-11. For a short overview of the problems regarding the historicity of the entrance story see Collins 2007: 513 . 
Jerusalem. The multitudes had welcomed him splendidly (Collins 2007: 516-21; Kinman 2005: 255-6). It is interesting that although the celebratory entries, triumphs and the $\pi \alpha \rho o v \sigma i \alpha$ were widely known in the Hellenistic world, the Old Testament and the Jewish writings of the Second Temple period do not recount Jewish rulers being hailed in triumph or $\pi \alpha \rho o v \sigma i \alpha$ (Kinman 2005: 237-8). ${ }^{4}$

Kinman estimates that the prefect Pilate, on his journey from Caesarea Maritima to Jerusalem, was most probably accompanied by 1,000 Roman soldiers, including both infantry and horsemen. The entry of Pilate into Jerusalem would have been impressive, and in the light of the situation, we have reasons to suppose that he was splendidly greeted by the city officials: i.e. the high priests and the aristocracy (Kinman 2005: 253-7; Kinman 1995: 16970). ${ }^{5}$ The arrival of Pilate would have taken place at approximately the same time as Jesus' arrival into the city (Kinman 1995: 159-72; Borg 1987: 173-4). On the other hand, the entry of Pilate should be compared with the entry of the Jewish pilgrims. If Pilate were accompanied by a thousand Romans, we should also note that the Jewish pilgrims ascending over the Mount of Olives numbered some tens of thousands.

4 David R. Catchpole (1984: 319-21) has argued that the entry of Jesus was created by the evangelists to resemble the well known triumphal entries of the time. Catchpole refers to a 'family of stories' - i.e. a family of entry stories which include the entries of Alexander the Great (Ant. 11:325-38), Apollonius (2 Macc. 4:21-2), Judas Maccabaeus (1 Macc. 4:19-25; Ant. 12:312), Jonathan Maccabaeus (1 Macc. 10:86; 11:60), Simon Maccabaeus (1 Macc. 13:43-8), Antigonus (Bell. 1:73-4; Ant. 13:304), Marcus Agrippa (Ant. 16:12-15) and Alexander (Bell. 2:105; Ant. 17:330-1). Catchpole claims that the stories of triumphal entries include clear patterns in which the final victory is won and the central figure is acclaimed a hero. After this there is a ceremonial entry into the city. Greetings and blessings of God are shared and dedicated, and finally the hero enters the temple (Catchpole 1984: 321). The Gospels' portrayal of Jesus' entry essentially differs however from the entries included in the 'family of stories', in which the actual vehicle of the hero - be it a horse, a donkey or royal chariots - is not emphasized or even mentioned. In all the Gospel accounts the ass is central. In a further comparison, Jesus' entry, in contrast with the family of entry stories, does not lead to a victory for the hero, but to his death on the cross. See also Davies and Allison 1997: 112-13.

5 Kinman refers to Bell. 3:93-7 in order to clarify the impressiveness of the Roman troops entering the city.
Jesus entered in the midst of that flow of pilgrims. Most of the Jewish pilgrims arrived at the city some days prior to the Passover in order to be purified for the feast (John 11:55; 12:1). It is to be noted that the Galilean pilgrims and Jesus would have entered the city from the east, over the Mount of Olives. Pilate on the other hand, accompanied by his soldiers, would have entered the city from the opposite direction, from the west. Thus these retinues would not have met on their arrival.

The Passover festival was the most popular of the Jewish pilgrimage festivals. E. P. Sanders estimates that the Passover was attended by 300,000-400,000 Jewish pilgrims (Sanders 1992: 125-8; see Bell. 2:280, 6:420-7; see also Kinman 2005: 252). This estimation is probably too high, but nonetheless it is clear that the pilgrimage crowds were huge. Of course not all the pilgrims arrived on the same day, but rather in a continuous flow throughout the week. As an example of the pilgrimage festivals' popularity it can be mentioned that once during the festival of the Tabernacles (Sukkoth) a whole town near Jerusalem was empty because its inhabitants had gone off to Jerusalem (Bell. 2:515). The importance of the pilgrim festivals and especially the Passover for the Jews during the first century can hardly be over-emphasized.

Why did the Roman soldiers not arrest Jesus immediately if he arrived in the city as a Jewish seeker after kingship? The Roman prefects were after all quick to use military action against popular prophetic figures and kingship-seekers whom they considered to be suspicious and revolutionary. From the point of view of the Roman authorities Jesus was most probably not considered dangerous. Jesus and his disciples were not known for violently opposing the Roman or Jewish aristocracies - the Herodians. The so-called 'sign prophets' of the $40 \mathrm{OS}$ and $50 \mathrm{OS} \mathrm{CE}$ were reputed to have had thousands of followers and they gathered them in certain places (Bell. 2:261; Ant. 20:97, 167, 169, 171; Acts 5:36-7) (see McKnight 2000: 197-232; Sanders 1985: 306). Jesus did not gather the masses in Jerusalem, but rather joined them on their pilgrimage to the holy city. It is also clear, as Collins points out, that Jesus' entry into Jerusalem was a spontaneous act (Collins 2007: 513-14). ${ }^{6}$

6 Collins lists three possible reasons why the Romans did not arrest Jesus right after or during his entrance into the holy city: 1) The crowds hailing the sign prophets, Theudas and the Egyptian, were much more populous. 2) Jesus' entry was 'spontaneous' and unlike the prophetic acts of Theudas and the Egyptian was not organized. 3) Pilate, as a procurator, was 


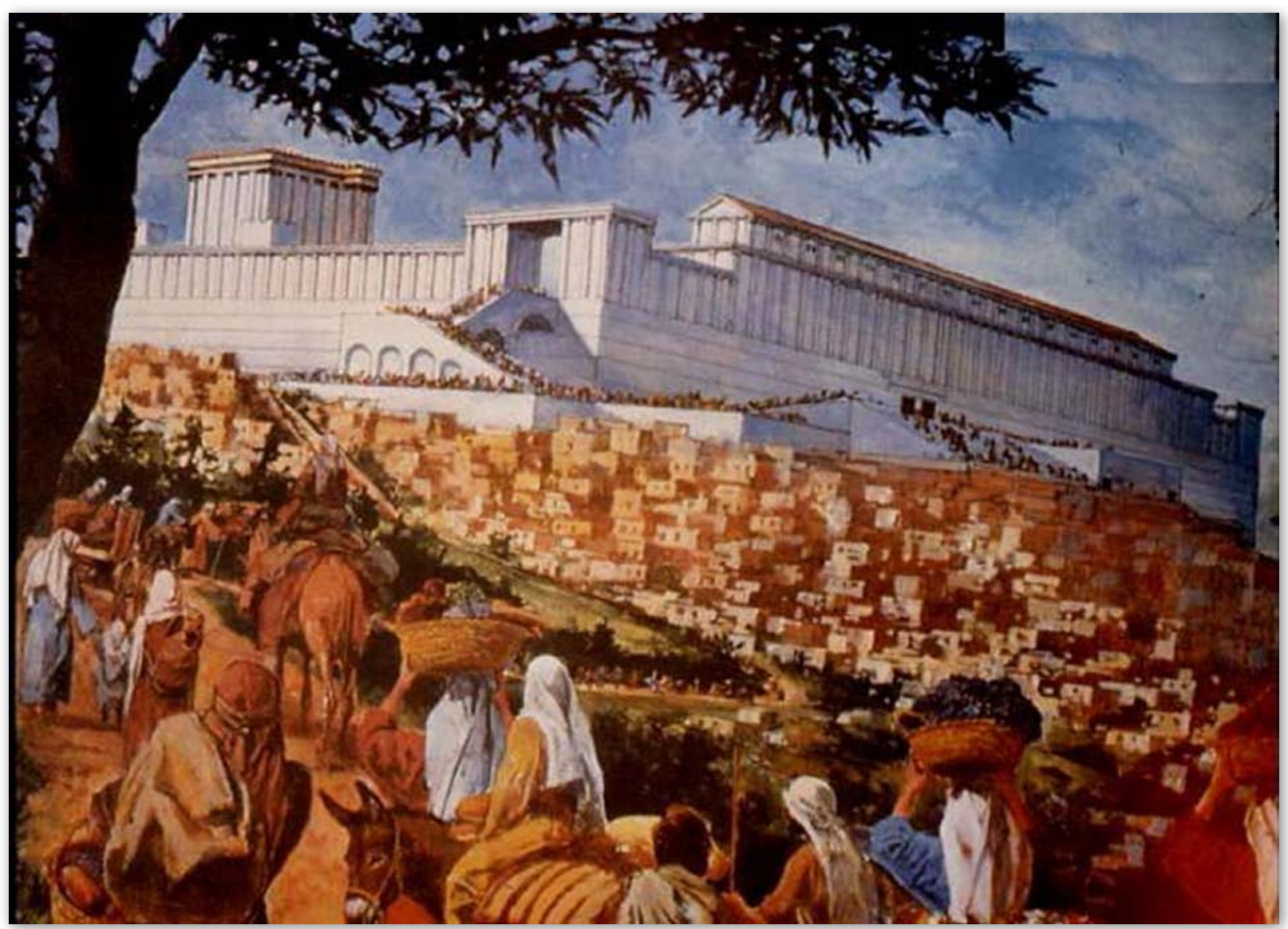

Looking from the southwestern corner, the artist portrays pilgrims arriving into Jerusalem. During the annual pilgrimage festivals hundreds of thousands of Jews gathered into the holy city.

The prophetic act of Jesus remained inspirational but enigmatic even for his disciples - how much more for the Romans and the Herodians?

Additionally the Romans would have been hesitant to strike in the midst of the thousands of Jewish pilgrims, just to arrest one man. The approximately 1,000 soldiers of Pilate would have been no match for the tens (or hundreds) of thousands of Jewish pilgrims who were in a mood of nationalistic and religious zeal. Josephus further clarifies that during the pilgrimage festivals there was a considerable potential for revolts to arise because these feasts inspired hopes of redemption among the Jews (Bell. 1:88; 6:290-309). Jesus was popular among the crowds - he

more lenient towards prophetic individuals than his successors. The disciples and Jesus are not portrayed to have acted in a militant or aggressive manner towards the Jewish ruling class or towards the Romans. Witherington 1990: 107. Ben Witherington argues that as the entry of Jesus would have taken place outside the city gates in the midst of the crowds, there is no need to expect a direct Roman response. See Eve 2002: 323 . inspired eschatological hopes of redemption. Attacking Jesus at the wrong moment could easily have been interpreted by the Jewish crowds as an attack on their own beliefs and hopes. An immediate and aggressive intervention in the wrong place and at the wrong time - in midst of enthusiastic Passover pilgrims could have caused a revolt and the deaths of many. Jerusalem had already, during the reign of Herod Archelaus (4 BCE-6 CE), borne the cost of a miscalculated intervention by a Roman cohort (Casey 1997: 306-32; see Bell. 2:5-13; Ant. 17:206-18).

Josephus states that on that occasion, which took place on Passover, 3000 Jews were slaughtered in the temple. Moreover, almost a whole Roman cohort was killed by the Jewish pilgrims. This terrible incident darkened the reputation of Archelaus in the eyes of the Jews and the Roman emperor. The hesitant mood of the Jewish (and Roman) authorities is reflected in the Gospels (cf. Mark 14:1-2; Matt 14:5, 21:46). We are to note that, in the case of Jesus, non-intervention should not be confused with delay (Casey 1997: 306-32). The Romans and Jewish authorities did eventually respond; not immediately, but with a 
delay of only a few days, and as a consequence Jesus was crucified as the 'King of the Jews'.

Jesus entered the city in the midst of a constant flow of the thousands of pilgrims, and this is why his entry probably went unnoticed by the Romans. According to Josephus the Roman soldiers were keeping watch over the temple from the Antonius fortress (Bell. 2:224, 5:243-7; Ant. 20:106-11). Their primary concern was to keep watch over the people in the temple and inside the city. The royal entry occurred on the Mount of Olives, outside the city. From the walls of the temple area and from the Antonius Fortress the Roman soldiers would not have been capable of effectively guarding the pilgrims entering the city from various directions. The distance from the temple area to the Mount of Olives was about 300 metres: the Roman soldiers' chances of seeing, hearing and understanding what was going on there on the Mount of Olives in midst of the pilgrims were quite limited (Kinman 2005: 253). As we have earlier noted, the Roman cohorts stationed in Palestine were mostly made up of Samaritan, Phoenician, and Tyrian soldiers. Many of them spoke the Phoenician language which was quite similar to the Aramaic spoken in Galilee (Sankamo 2012a: 154-6). This is why at least some of these Roman soldiers would have been capable of understanding the Aramaic and/or Hebrew language of the Galilean pilgrims. There are, however, as we have seen, several practical reasons why the Romans would not have arrested Jesus on the spot.

Marcus J. Borg, Kim Huat Tan, Brent Kinman and Paula Fredriksen claim that Jesus' entry was triumphal in the sense that a crowd, mostly consisting of Jesus' followers and other sympathizers, actually greeted him with excitement (Fredriksen 1999: 241-5; Tan 1997: 147-8; Kinman 2005: 252; Borg 1987: 174). ${ }^{7}$ According to Sanders Jesus was greeted by shouts of Hosanna only by a small group of disciples (Sanders 1985: 306, 308). The Gospels are quite imprecise in stating how many people welcomed Jesus in particular. Since Matthew and Luke are clearly relying on Mark, we shall concentrate on the Gospel of Mark.

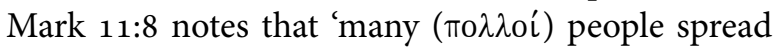
their cloaks on the road, and others spread leafy branches $\left(\sigma \tau \iota \beta \alpha^{\prime} \delta \alpha \varsigma\right)$ '. From Mark it is possible to get the impression that the crowds accompanying Jesus did not consist of thousands, not even of hundreds of people. The sentence structure of Mark 11:8 indi-

7 According to Borg the people who hailed Jesus were his 'supporters and sympathizers'. cates that the 'many' does not refer to the multitudes of the pilgrims, but rather to the disciples of Jesus. The 'many' of Jesus' followers saluted him by laying their coats before him. Matthew follows Mark's sentence structure - the 'very large crowd' ( $\delta$ d' $\delta^{\prime} \pi \lambda \in \hat{\imath} \sigma \tau o \varsigma$ " $\chi \lambda$ $\chi \circ$, Matt. 21:8) comes from Jesus' followers, not from the vast multitudes of pilgrims (Kinman 2005: 250-2; Kinman 1995: 171-2). ${ }^{8}$ Luke hints most clearly that the entry of Jesus was not accompanied by great crowds greeting him with joy. He explicitly mentions that only the disciples laid clothes before Jesus and burst into joyous shouts (19:36-38). Because of their joy (19:39) some Pharisees from among the crowds asked Jesus to silence his disciples. So far all the practical details support the conclusion that Jesus' entry as a prophetic sign was aimed at the Jewish pilgrims, not the Roman soldiers. John (12:16) indicates that the entry of Jesus remained, for the moment, quite enigmatic even for the disciples of Jesus: 'His disciples did not understand these things at first'. The Romans perhaps did not even notice the entry of Jesus, and if they did, the ass ride would not have raised alarming suspicions.

\section{Royal undertones and the entry of Jesus}

The Gospels of Mark, Matthew and John state that the crowds acclaimed Jesus with shouts of Hosanna (Mark 11:9; Matt. 21:9; Luke 19:38; John 12:13). Nowhere else in the Gospels is Jesus greeted with Hosanna shouts (Dunn 2003: 641-2). Hosanna shouts are not found in the Pauline letters, the earliest writings of the New Testament. In the Gospels the

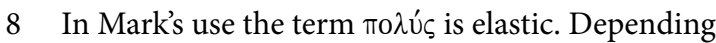
on the context it can refer to dozens of individuals (Mark 2:2, 15; 5:26) to several thousand people in Mark 6:34. Matthew emphasizes that a very large

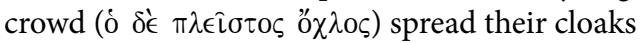
(21:8), and that the crows (oi $\delta$ '́ oै $\chi \lambda \mathrm{ol}$ ) who came after and before him, shouted Hosanna (21:9). When Jesus entered Jerusalem the whole city ( $\left.\pi \hat{\alpha} \sigma \alpha \dot{\eta} \pi{ }^{\prime} \lambda \iota \varsigma\right)$ was in turmoil (21:10; see also 2:3-4). The Gospel of John mentions that a big crowd of people (o oै $\chi \lambda \mathrm{o} \varsigma$ $\pi 0 \lambda \dot{u} \varsigma, 12: 12-13)$ greeted him with palm branches and shouts of Hosanna. John says that the raising up of Lazarus had gained the peoples' (o 'o $\chi \lambda \mathrm{o} \varsigma, 12: 17-18$ ) interest in Jesus to the extent that the Pharisees mur-

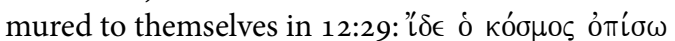
$\alpha \dot{\tau} \tau$ ov̂ $\dot{\alpha} \pi \hat{\eta} \lambda \theta \in \nu$. If we pass over Matthew's mention of the whole city $(21: 10,2: 3-4)$ and John's mention of the world (12:29) as redactional creations, it seems that the crowds welcoming Jesus were not so huge, and perhaps they consisted mainly of Jesus' disciples. 
singing of Hosanna indicates a citation of Ps. 118:26. ${ }^{9}$ Hosanna means in both Hebrew and Aramaic 'save, please!' In this Psalm God is honoured as King.

The Mishnah and the Talmud give clarification in that according to the tradition the Great Hallel (Pss. 113-18) was sung especially on the feasts of Passover and Tabernacles (m. Sukkah 4:5; m. Pesah. 5:7; b. Arak. 1oa; t. Sukk. 3:2). ${ }^{10}$ Although we do not have any written explicit testimonies of the Great Hallel from the writings of the Second Temple period, Josephus, Philo (Spec. Leg. 2:148), the Book of Jubilees (49:6) and Mark (14:26) reveal that during the Passover celebration, as part of the Passover Haggadah, psalms were sung and prayers recited. The Mishnah states that the Great Hallel was sung at the same time as the sacrifices were offered in the temple (m. Pesah. 5:7) and during the Passover meal (m. Pesah. 10:6). It seems that the singing of the Great Hallel was already part of the Passover Haggadah during the Second Temple period, and there is of course the possibility that it was sung by the pilgrims as they arrived in Jerusalem (Kinman 2005: 246; Safrai 2006: 48-9). ${ }^{11}$

In the story of Jesus' entry the crowd welcomes Jesus with shouts of Hosanna. Mark 11:9-10 combines the Hosanna of Ps. 118:25-26 and the longed arrival of the kingdom of David. Most probably some kind of a messianic interpretation of Ps. 118 was known during the first century (Marcus 2009: 780). ${ }^{12}$

9 The Greek word $\omega \sigma \alpha \nu \nu \alpha$. is a translation of the Aramaic expression הושטע נא. In Hebrew the expression is הוֹשיעה :The meaning of both the Aramaic and the Hebrew expression is 'Save, please!' See Collins 2007: $512,519$.

10 See m. Pesah. 5:7; m. Sukkah 3:9, 11; 4:5, 8. For the scholarly discussion of the use of the Great Hallel during the feasts of Passover and Tabernacles, see Marcus 2009: 774-5; Kinman 1995: 57; Kinman 2005: 244-6; Evans 1999: 382-3; Han 2002: 179; Safrai 2006: 48-9.

11 In $\mathrm{m}$. Pesah. 10:6 the rabbinic authorities are already arguing over in what order the psalms are to be sung in the Passover Haggadah. This fact supports the conclusion that the Hallel was already sung as part of the Passover Haggadah in the early first century. Watts 2007: 314. Rikki E. Watts states that in the first century the last psalm of the Great Hallel (Ps. 118) was connected with hopes of a new eschatological exodus, a new Davidic King and the restoration of the temple of Jerusalem.

12 In commenting on Mark 11:9 Joel Marcus states the following: "Hosanna" and "Blessed is he who comes in the name of the Lord" are both drawn from Psalm
The Aramaic Targum had translated and interpreted Ps. 118:25-6 in a way that combines Hosanna and Davidic kingship. According to the Targum Ps. 118 the 'stone that the builders rejected' was the son of Jesse, David, whom the priests will now bless from the temple (Targum Ps. 118:22, 26b) (Hultgren 2008: 287-8; Evans 1999: 382-3). Mark implicitly indicates that the singing of Hosanna acclaimed Jesus as the Davidic king (Marcus 2009: 779-80). In Mark 11:10 the crowd cries out $\epsilon \dot{U} \lambda \sigma \gamma \eta \mu \mu^{\prime} \nu \eta \dot{\eta}$ '́ $\rho \chi 0 \mu \mu^{\prime} \nu \eta \beta \alpha \sigma \iota \epsilon^{\prime} \alpha$

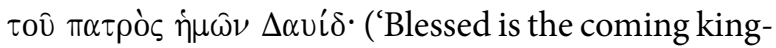
dom of our ancestor David!'). Matthew has redacted this Markan reference to David in line with his Sonof-David Christology. In Matt. 21:9 Jesus is explicitly acclaimed as the Son of David. ${ }^{13}$ Luke (19:38) does not mention David, but he claims that the crowd

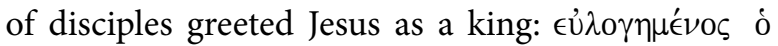

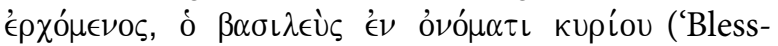
ing is the king who comes in the name of the Lord!'). Luke has certainly downplayed some of the central royal overtones in the Markan story of Jesus' entry. Besides leaving out the reference to David and the shouts of Hosanna, Luke has also omitted the 'leafy branches' (Mark 11:8; Matt. 21:8; John 12:13), which functioned as nationalistic symbols in late Second Temple Judaism. ${ }^{14}$

In John 12:13 the crowd hails Jesus as the king of Israel. In spite of the fact that John does not explicitly mention David, it is clear that his version of the entry

118 , which was probably already interpreted eschatologically and perhaps messianically, in first-century Judaism' (Marcus 2009: 780). On pp. 774-5 Marcus states that 'Starck and Billerbeck (I.849, 876; 2.256) and Jeremias (Eucharistic Words, 256-60) assert that a messianic understanding of Ps. 118:26 was already present in the Judaism of Jesus' time. This is possible, since the NT passages that use Ps. 118:26 (the present passage and Matt. 23:39= Luke 13:35) assume rather than argue for a messianic interpretation, and other NT and early Christian passages (Mark 12:10; Acts 4:11; 1 Pet. 2:7; Barn. 6:4; Acts of Peter 24) reveal a tendency to read Psalm 118 Christologically.'

13 Matthew calls Jesus 'Son of David' altogether nine times. In Mark Jesus is called Son of David only three times. See Paffenroth 1999.

14 Luke's omission of the branches is best explained by two reasons. First, the foliage is connected with the Feast of the Tabernacles (Sukkoth) and Hanukkah (Lev 23:40; Neh 8:13-15; 1 Macc. 13:51) - not with the Feast of Passover. Secondly, since Maccabean times the foliage was seen as a nationalistic symbol connected to military victories and the re-dedication of the temple (1 Macc. 4:36; 13:51; 2 Macc. 10:7). See Kinman 1995: 116-17; Kinman 2005: 245. 


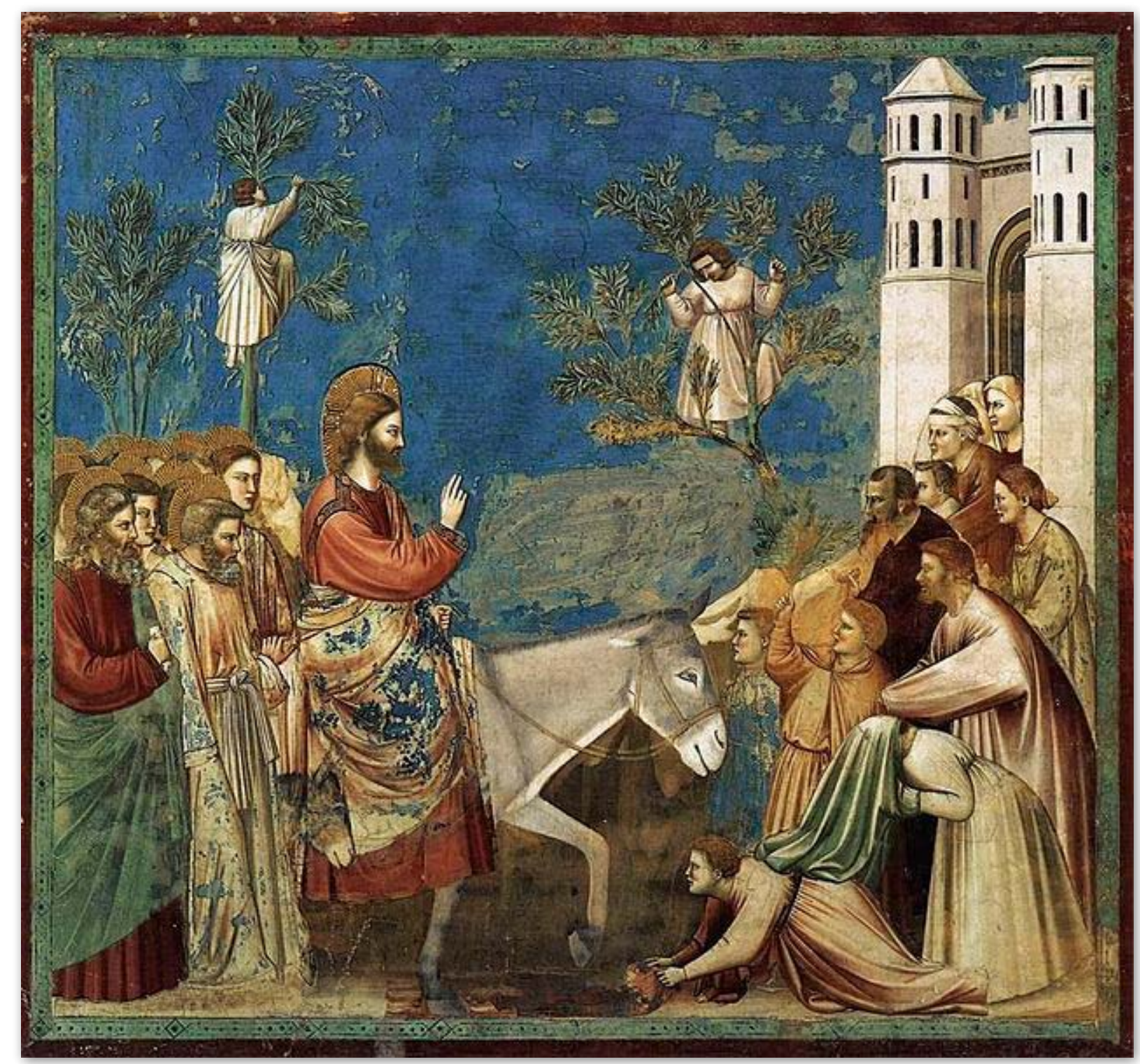

Some days prior to the crucial Passover, Jesus acted out his prophetic sign of entering into the city on an ass. The fact that all the four Gospels retell this episode testifies that his entry was regarded as significant, royal and prophetic. Entry into Jerusalem by Giotto di Bondone, in Arena Chapel, Padoa, Italy, c. 1305.

contains a Davidic atmosphere due to the mention of the 'king of Israel', the palm branches and the ass, which is connected with the prophesy of the Davidic king of Zion in Zech. 9:9 (Meier 2001: 54-5). ${ }^{15}$ It seems that the early tradition of the entry of Jesus into Jerusalem contained the idea that some sympathizers and disciples of Jesus greeted him in particular with shouts of Hosanna and they expressed hopes con-

15 The lack of direct mention of David in John's version of Jesus' entrance is not surprising. In general the Gospel of John does not demonstrate interest in the Son-of-David Christology, and thus the Davidic atmosphere even in John's version of the event is striking. cerning the kingdom of David (ibid. 55). The royal atmosphere in the entry of Jesus is strengthened due to the fact that the Synoptics (Mark 11:8) mention

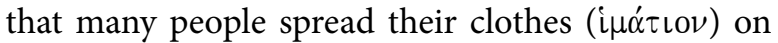
the road. Both the Jewish (2 Kgs. 9:13; Judith 15:1114) and the Roman tradition (Plutarch, Cato Minor 12; Plutarch's Livres 8:760-1) are familiar with this manner of showing respect for the one making an entrance.

Josephus and the writer of 1 Macc. indicate that seekers of kingship or some kind of national leadership could promote their status by wearing a diadem (Bell. 2:57, 62; cf. Bell. 1:70). Interestingly none of the Gospels allude to Jesus placing this widely 
acknowledged royal symbol on his head. Josephus writes that the death of Herod the Great inspired several Jews to revolt and to set themselves up as kings. In Perea a Jewish slave of Herod the Great, Simon, 'put a diadem upon his own head' (Bell. 2:57-9/Ant. 17:273-6). Elsewhere a shepherd called Athrongeus ventured to set himself up as king. As a sign of this he began to wear a diadem (Bell. 2:60-2/Ant. 17:27881 ). The diadem was clearly a symbol of kingship. Both of those royal pretenders, who placed a diadem upon their heads, i.e. the shepherd called Athrongeus and Simon, were brutally killed by the Herodian and Roman armies. If a rebel leader placed a diadem on his head, he was asking for serious trouble. It is worth noting that both Simon and Athrongeus actively fought against the Herodians and the Romans. Simon 'burned down the royal palace at Jericho, and plundered what remained. He also set fire to many of the king's other houses in several places of the country' (Ant. 17:274). Athrongeus and his brothers 'killed a great many both of the Romans and of the king's forces' (Ant. 17:281). Needless to say, nothing of this sort of activity is associated with Jesus.

A 'purple coat' and a 'golden belt' were also well known symbols of royalty (1 Macc. 8:14; 10:20, 61-4; 11:58). Simon the Maccabee was granted national leadership and the office of high priest. As a sign of his royal and priestly status, he began to wear a purple tunic and a golden belt (1 Macc. 14:34-44). $\mathrm{He}$ also forbade all other priests and citizens to wear such ornaments. The purple coat and the diadem were recognised both by the Jews and the Romans (John 19:2, 5; Mark 15:17-20; Bell. 7:123-5) as royal and priestly symbols. Jesus' entry according to the Gospels lacked these explicit and typical royal symbols - in other words the diadem and purple coat. If Jesus had worn such fabrics he would actively and explicitly have been putting across a royal message. However the royal undertones of Jesus' entry are - to a great extent - due to the reactions of the bystanders: they hail him with shouts of Hosanna and wave branches. In this prophetic act the bystanders are playing an active part. Jesus himself is quite passive. He does not wear a diadem or a purple coat. He only rides on an ass. He joins the thousands of Jews on their pilgrimage into the holy city.

Kinman is certainly correct in emphasizing that the apparently royal atmosphere of Jesus' entry was problematic or 'embarrassing' for the early Christians of the first century. The Christians were occasionally accused of being disloyal towards the Emperor (cf. Acts 17:7). The story of the royal entry of Jesus could possibly have caused them political trouble. Kinman uses the criterion of embarrassment to support the historicity of the royal entry of Jesus (Kinman 2005: 229-33, 258). The entry of Jesus, as told in the Gospels, resonates with popular messianic ideas of the Second Temple period, which anticipated the rise of a new David, a royal Messiah (Ps. Sol. 17-18) (see Sankamo 2012b: 298-301; Fredriksen 1999: 119-24; Kinman 2005: 242-3; Collins 1995: 68; Horsley and Hanson 1985: 109-10). Understandably the Romans - especially after the experience of the Jewish war were aggressively against this kind of messianic hope (see Eusebius, Church history, III, 12, 19-20). ${ }^{16}$ The Gospel of Mark was written around the year $70 \mathrm{CE}$, and therefore its portrayal of Jesus coming into Jerusalem as a hailed king, and later crucified as the king of the Jews, certainly awoke associations with the illfated Jewish kingship-seekers.

Over the past 50 years several scholars have associated Jesus' death penalty with the accusation of royalty (Collins 2007: 513; Sanders 1985: 306; Fredriksen 1999: 142-3; Kinman 2005: 233-5). Fredriksen states that 'the entry and the execution fit each other precisely'. She explains that 'Jesus parades into the city before Passover like a king (Mark 11:710); and he is executed by Pilate as if he had, indeed, claimed to be one (Mark 15:2-26)' (Fredriksen 1999: 142). ${ }^{17}$ Kinman makes use of the criterion of effect in order to show that the entry of Jesus should be seen in the light of the outcome, that is to say the Jewish high priests' accusations made against him at his trial and the eventual death penalty on the cross (Kinman 2005: 233). Kinman states that Jesus' accusers could have used the royal entry as a political charge against Jesus in front of Pilate (ibid. 235, 250). As I have

16 The Emperors Vespasian (69-79 CE) and Domitian (81-96 CE) were suspicious - to the extreme - of all Jews who claimed to be descendants of David.

17 This same connection between the royal entry and the accusation of claiming to be king is also apparent in the Gospel of John. Jesus' entry is seen as royal (John 12:13) and the accusation before Pilate is concentrated on Jesus being the king of the Jews (19:2-5, $14-15,19-20)$. Fredriksen notes that in the 28 verses of John 19:1-18 the word 'king' or 'kingdom' appears 15 times (Fredriksen 1999: 143). Kinman (2005: 234) states that 'while mention of Jesus as king is found in each of the Gospel trial narratives, there is only one event in the Synoptics prior to his trial where Jesus is called "king" - the Entry into Jerusalem, which, according to the Gospels, occurred just a few days before his arrest and trial'. 
argued above, Jesus' entry into Jerusalem most probably would not have upset the Roman soldiers to such an extent that they would have arrested Jesus in the midst of the pilgrim crowds. However it is possible that the entry was later presented for Pilate in order to convince him of the potential danger Jesus posed.

It is apparent that in the trial accounts of both Mark and John the Jewish high priests are said to have declaimed Jesus in front of Pilate as primarily politically seditious and a rival. He is called the 'King of the Jews' (Mark 15:2, 9, 12, 16-19, 26, 32). If Jesus had used the popular kingship symbol, the diadem, in his entry it can be assumed that the high priests would have mentioned it to Pilate. The silence regarding the ass would however be understandable because the Romans and the non-religious Jews would not have seen the ass ride as a royal and revolutionary act. We shall now survey the significance of the ass.

\section{The royal riddle of the ass}

The ass is emphasized in all the versions of the entry story. In Judaism at that time the ass was considered to be both the beast of burden and of royalty (Gen. 49:11; Zech. 9:9). It was viewed as a common work horse (Tatum 1998: 131, 140). Tatum indicates that in Hellenistic conceptions the ass was not an honoured animal. It was occasionally connected with malicious anti-Semitism (ibid. 131-2). ${ }^{18}$ Interestingly Josephus states in Ant. 18:356 that the Jewish brigand army leader Anileus attacked a Parthian noble, Mithridates, in the 4OS CE and humiliated him by forcing him to ride naked on an ass. During a battle Anileus captured 'Mithridates alive, and set him naked upon

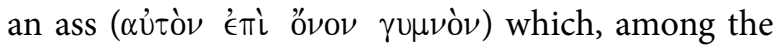
Parthians, is esteemed the greatest reproach possible. From the point of view of the religious Jews the entry of Jesus on a colt-ass was pregnant with some implicit royal and prophetic meanings (cf. Zech. 9; 1 Kgs. 1; Gen. 49), but from the point of view of the Romans the entry on an ass transmitted a message that was quite a-triumphal.

The use of the ass certainly carries a message because in Mark it is emphasized with such accuracy. In Mark 11:2-6 Jesus sends two of his disciples

18 In the anti-Semitic claims of the Hellenistic period it was stated that in the temple in Jerusalem there was a marble statue of a heavily bearded man seated on an ass (Bib. Hist. 34:1.3, Diodorus). The Jews were accused of keeping and worshipping an ass's head in the temple (C. Ap. 2:80-8, 114, 120). to look for a certain young ass in the village. It is explicitly noted in Mark 11:2 that the disciples are to untie and bring Jesus a 'colt that has never been rid-

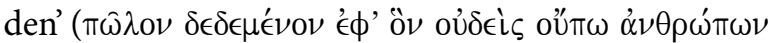
'є $\kappa \dot{\alpha} \theta\llcorner\sigma \in \nu)$. The evangelists use different words for the ass. The Synoptics refer to it as a young male ass or colt ( $\pi \hat{\omega} \lambda \mathrm{O}$, Mark 11:2; Matt. 21:2; Luke 19:30) while John calls it a young ass (ovó́pıov, John 12:14). The words have basically the same meaning, but $\pi \hat{\omega} \lambda$ o $\zeta$ has a specific background in the LXX. The word $\pi \hat{\omega} \lambda \circ \varsigma$ as in Mark 11:2 is found identically in LXX Gen. 49:11 (x2) and Zech. 9:9. It is to be noted that these are the only passages in the LXX were the specific word is used identically in this form. Consequently it seems that Mark 11 uses the word $\pi \hat{\omega} \lambda$ o $\zeta$ in order to evoke the royal and humble images deriving from Gen. 49:11 and Zech. 9:9 (Collins 2007: 518). The young male ass óvópıov lacks specific parallels in the LXX.

In addition to the young male ass ( $\pi \hat{\omega} \lambda \circ \varsigma)$ Matthew

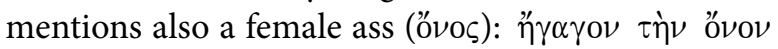

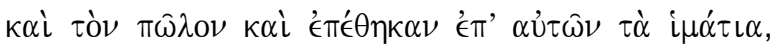

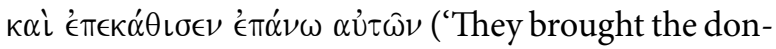
key and the colt, and put their cloaks on them, and he sat on them', Matt. 21:7.) In Matthew's text this might imply that the colt could not walk to the city without its mother leading the way. The likeliest explanation for the two donkeys of Matthew is that the evangelist intended to connect Jesus' entry into Jerusalem with the prophesy of Gen. 49:11 which literally mentions both a male and a femal ass: tòv $\pi \hat{\omega} \lambda$ ov

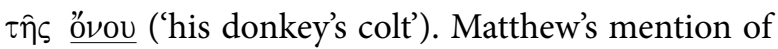
the two animals might also reflect Zech. 9:9 which indicates that the king rides on two animals: $\epsilon \pi i$

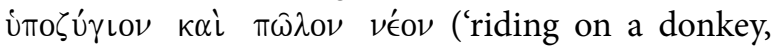
on a colt, the foal of a donkey'). The word o'vos is a typical word for a female ass. In the LXX this epithet is repeatedly used for an ass.

Both the Synoptics and John underline the young age of the juvenile ass ( $\pi \hat{\omega} \lambda \circ \hat{\zeta}$ // ó $\nu$ ó Jesus rode into the city. The youth of the colt reflects Zech. 9:9 which describes the colt of the king of Zion

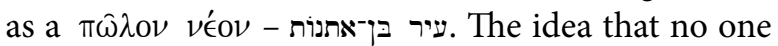
had sat on the colt (Mark 11:2; Luke 19:30) indicates naturally that the colt was put aside for a special purpose, that is, for a holy and royal purpose. Mishnah Sanh. 2:5 states that nobody other than the king was allowed to ride on the king's horse (Collins 2007: 518-19; Kinman 2005: 237).

Adela Yarbro Collins (2007: 518) claims that it is essential and striking that 'Jesus rides a donkey and not a horse, or even a mule. In keeping with the 
instruction about a leadership of service in Mark 10:41-45, Jesus does not ride a horse or in a chariot, as a Roman celebrating a triumph would'. Jesus does not even ride a mule (ijuiovos) which would recall the narrative of Solomon's anointing as king:

So the priest Zadok, the prophet Nathan, and Benaiah son of Jehoiada, and the Cherethites and the Pelethites, went down and had Solomon ride on King David's mule, and led him to Gihon. There the priest Zadok took the horn of oil from the tent and anointed Solomon. Then they blew the trumpet, and all the people said, 'Long live King Solomon!' And all the people went up following him, playing on pipes and rejoicing with great joy, so that the earth quaked at their noise. (1 Kgs. 1:38-40)

Besides 1 Kgs. 1 there are several other passages in which mules, donkeys and the colt-ass are associated with kingship. Saul searched for donkeys but found kingship (1 Sam. 9). According to Gen. 49:11 the ruler shall arise from Judah: 'Binding his foal to the vine and his donkey's colt to the choice vine, he washes his garments in wine and his robe in the blood of grapes'.

Zech. 9:9 states that the king of Zion shall ride on a colt-ass: 'Rejoice greatly, O daughter Zion! Shout aloud, O daughter Jerusalem! Lo, your king comes to you; triumphant and victorious is he, humble and riding on a donkey, on a colt, the foal of a donkey.'

Was the colt ass already being associated with royal messianism during the first century? Could it be possible that the entry story of Jesus was created in the light of Zech. 9:9 and some current messianic expectation? We have no explicit evidence that Zech. 9:9 was interpreted as referring to the Messiah during the Second Temple period. The rabbinic texts connecting Zech. 9:9 with the Messiah are from the third century BCE (Witherington 1990: 107; Kinman 2005: 244; Kinman 1995: 108). ${ }^{19}$ In the writings of the DSS and the Pseudepigrapha Zech. 9:9 is never used as a messianic prophecy.

We should, however, not draw far-reaching conclusions on argumentation based on ex silentio. Despite not knowing of explicit messianic expectations connected with Zech. 9:9 during the Second Temple period, it is clear that Zech. 9:9 deals with the

19 Kinman refers to b. Sanh. 98a, 99a. See also Qohelet Rabbah 1.28. prophecy of Davidic kingship. Moreover, the colt-ass is associated with royalty in Gen. 49; 1 Sam. 9; 1 Kgs. 1 and Zech. 9. On the basis of Zech. 9 and 1 Kgs. 1 the Jews of the Second Temple period could certainly recall that the king of the Jews would ride into Jerusalem on an ass. It is likely that several Jews, who knew the Jewish scriptures well, could have made the connection between Zech. 9, 1 Kgs. 1 and Jesus' entry into Jerusalem on an ass (Dunn 2003: 642; Kinman 2005: 241-2). This is even more so as we recall the context. It is plausible that religious Jews coming into Jerusalem in the midst of the populous crowds of Passover pilgrims, could have associated the ass ride of Jesus - the prophetic figure who proclaimed the kingdom of God - with royalty.

The eschatological hope of Zech. 9:9-10 is centred on the coming of the righteous king of Zion into Jerusalem. The entry of the king would inaugurate a national restoration of Israel. The scattered people would be gathered back into the land, which would then prosper and be densely populated (Zech. 8:7; 9:11-12, 16-17; 10:8-11). The triumphant but lowly king of Zion would destroy the armour and the chariots of Ephraim and Jerusalem and establish universal peace (see Collins 1995: 31-2). ${ }^{20}$ His rule or dominion (משל) would stretch from 'sea to sea, and from the River to the ends of the earth' (9:10). This description of the extent of the dominion of the king resembles with the several idealistic and prophetic visions of the size and influence of the Promised Land (Gen. 15:18-21; 1 Kgs. 5:1, 4; 8:65; Pss. 2:8, 72:8) (Meyers and Meyers 1993: 136; see Collins 1995: 32).

\section{The meaning of Jesus' entry}

The prophetic act of Jesus' entry into Jerusalem resonates clearly within the Jewish symbolic universe: the Passover, the pilgrim crowds, Jerusalem, the ass, the prophecies and the singing of the Hallel. The closest parallels to Jesus' entry are found not from the Hellenistic triumphs and celebratory entries, but rather from the royal entries depicted in Zech. 9 and 1 Kgs. 1. Jesus as a prophetic and religious figure, with the reputation of being a successful healer, exorcist and preacher, aroused aspirations among the Jews for deliverance and for the kingdom of God. As Jesus came up into Jerusalem from the Mount of Olives at

20 The Old Testament contains several prophesies in which the Davidic king will establish a kingdom of universal peace and justice: Isa. 9:4-6 (2:4); 16:5; Mic. 5:4; Jer. 23:5-6; 2 Sam. 7:9-14. See also Ps. 76. 
Passover, it seems credible that the hopes of redemption intensified around him. The historical (Ex. 12-14) and eschatological (Bell. 6:290-5) gaze of the Passover Festival focused on the redemption of Israel. The sign prophets' popularity during the second half of the first century CE testifies that several Jews were in a mood for expecting signs of deliverance and restoration (Ant. 18:85-7; 20:97-8, 167-71; Bell. 2:261-2; cf. Acts 5:36-7). The hopes of redemption and deliverance were especially strong when the Jews gathered into Jerusalem during the pilgrimage feasts.

To admit that Jesus entered the city on an ass some days before his death leaves open what the intended meaning, and the eventual aim of the entrance were. Obviously Jesus did not explain his entrance. If he had explained it we could expect to find that explanation in the Gospels (Tan 1997: 148-9). Scholars on the other hand have offered several optional answers for the question of the significance of Jesus' prophetic entrance (ibid. 11-21). ${ }^{21}$ Some have argued that Jesus was intentionally fulfilling Zech. 9:9 in a humble, but messianic way. Others have argued that the entrance was designed to spark a coup, led by the Zealot-like King Jesus. According to this view Jesus was to be hailed as the king of a rather earthly kingdom. Such a revolutionary Jesus is reminiscent of the 'Egyptian' sign prophet who according to Josephus gathered 30,000 supporters and planned to rally down the Mount of Olives into the city (Bell. 2:261-3; see Brandon 1967: 332-40). Some have favoured the view that the entry was not messianic, but rather a demonstration, in line with the old prophets' style (see Tatum 1998: 129-30).

21 Tan has enlisted scholars' views of Jesus' intentions and aims for his entry on an ass. James D. G. Dunn (2003: 791) divides the scholars' different reasons for Jesus' arrival in Jerusalem into three groups: 1) Jesus simply felt the need to deliver his urgent message of the Kingdom of God in the capital city, Jerusalem. Perhaps he had hopes that the city would repent and believe his message. 2) Jesus wanted to confront the political and religious leadership, and possibly pose a rather earthly kingdom in Jerusalem, led by himself or God. 3) Jesus thought that if the Kingdom was about to come, it would most obviously 'happen' in the mother city of the Jews, in Jerusalem. Luz 2005: 10-12. Ulrich Luz states that Jesus' entry and the temple act are usually interpreted in two ways; 1) some see it as a 'large-scale political act that was then played down by the evangelists'; 2) others see it as a symbolic action, which can be understood in various ways.
More recently several scholars have claimed that the entry and the temple act are to be understood as prophetic, symbolic actions (Luz 2005: 10-11). Tan insists that Jesus saw that through his entry the rule of God was ushered into Jerusalem (Tan 1997: 151, 154, 157). W. D. Davies, Dale C. Allison and E. P. Sanders agree that Jesus probably deliberately planned and enacted the entry as a symbolic act indicating that the kingdom of God was coming. By means of the entrance he also clarified his own role in the kingdom (Davies and Allison 1997: 114; Sanders 1985: 308). I maintain that Jesus quite certainly planned his entry into Jerusalem - riding on a young ass would have recalled Zech. 9:9 and 1 Kgs. 1. Jesus' riding is thus to be seen as a prophetic symbol; an act in accordance with a prophetic paradigm. Through Jesus' entry the kingdom of God was ushered into the city and challenged it to realize the eschatological moment and visitation (cf. Pss. Sol. 11). The traditions indicate that in Jerusalem Jesus talked about themes which can be associated with restoration eschatology (Matt. 19:28-9/Luke 22:29-30; Mark 13:24-7). These themes fit neatly with the royal entry of Jesus.

In his studies Dr Juho

Sankamo has concentrated on Jewish universalism of the late Second Temple period. Sankamo defended his doctoral thesis - Jesus and the

Gentiles - in 2012. In a scholarly essay published in 2012 Sankamo surveyed Josephus' views concerning eschatological universalism. Sankamo continues his post-doctoral studies at Åbo Akademi University. Email: juho.sankamo(at)evl.fi

\section{Bibliography}

Borg, Marcus J., 1987. Jesus. A New Vision: Spirit, Culture, and The Life of Discipleship (New York, Harper \& Row)

Brandon, S. G. F., 1967. Jesus and the Zealots: A Study of the Political Factor in Primitive Christianity (Manchester University Press)

Casey, P. M., 1997. 'Culture and historicity: the cleansing of the temple', Catholic Biblical Quarterly 59(2), pp. 306-32

Catchpole, David R., 1984. 'The "triumphal" entry' in Jesus and the Politics of His Day, eds Ernst Bammel, and C. F. D. Moule (Cambridge University Press), pp. 319-34

Chancey, Mark A., 2005. Greco-Roman Culture and the Galilee of Jesus (Cambridge University Press) 
Collins, Adela Yarbro, 2007. Mark: A Commentary (Minneapolis, Fortress Press)

Collins, John, J., 1995. The Scepter and the Star: The Messiahs of the Dead Sea Scrolls and Other Ancient Literature (New York, Doubleday)

Davies W. D., and Dale C. Allison, Jr, 1997. A Critical and Exegetical Commentary on the Gospel According to Saint Matthew. Volume III. Commentary on Matthew XIX-XXVIII (Edinburgh, T \& T Clark)

Dunn, James D. G., 2003. 'Jesus remembered' in Christianity in the Making, vol. 1 (Cambridge, William B. Eerdmans Publishing Company)

Evans, Craig, A., 1999. 'Jesus and Zechariah's messianic hope' in Authenticating the Activities of Jesus, ed. Bruce Chilton, and Craig A. Evans (Boston, Brill), pp. 373-88

Eve, Eric, 2002. The Jewish Context of Jesus' Miracles (London, Sheffield Academic Press)

Fredriksen, Paula, 1999. Jesus of Nazareth: King of the Jews. A Jewish Life and Emergence of Christianity (New York, Vintage Books)

Han, Kyu Sam, 2002. Jerusalem and the Early Jesus Movement: The Q Community's Attitude Toward the Temple (London, Sheffield Academic Press)

Horsley, Richard A., and John S. Hanson, 1985. Bandits, Prophets, and Messiahs: Popular Movements in the Time of Jesus (Minneapolis, Winston Press)

Hultgren, Stephen, 2008. 'The incident at the temple as the occasion for Jesus' death: meeting some objections' in Redefining First-Century Jewish and Christian Identities: Essays in Honor of Ed Parish Sanders, ed. Fabian E. Udoh with Susannah Heschel, Mark Chancey, and Gregory Tatum (University of Notre Dame Press), pp. 283-96

Kinman, Brent, 1995. Jesus' Entry into Jerusalem: In the Context of Lucan Theology \& the Politics of His Day (Leiden, E. J. Brill)

-2005. 'Jesus' royal entry into Jerusalem', Bulletin for Biblical Research 15(2), pp. 223-60

Laaksonen, Jari, 2002. Jesus und das Land. Das Gelobte Land in der Verkündigung Jesu (Åbo Akademi University Press)

Luz, Ulrich, 2005. Matthew 21-28, trans. James E. Crouch (Minneapolis, Fortress Press)

Marcus, Joel, 2009. Mark 8-16: A New Translation with Introduction and Commentary (London, Yale University Press)

McKnight, Scot, 2000. 'Jesus and prophetic actions', Bulletin for Biblical Research 10(2), pp. 197-232

Meier, John, P. 2001. 'From Elijah-like prophet to royal Davidic messiah' in Jesus: A Colloquium in the Holy Land, ed. Doris Donelly (New York, Continuum), pp. 45-83

Meyers Carol, L., and Eric M. Meyers, 1993. Zechariah 9-14: A New Translation with Introduction and Commentary (Toronto, Doubleday)

Paffenroth, Kim, 1999. 'Jesus as anointed and healing Son of David in the Gospel of Matthew', Biblica 8o, pp.

547-54
Safrai, Shmuel, 2006. 'Early testimonies in the New Testament of laws and practices relating to Pilgrimage and Passover' in Jesus' Last Week, ed. R. Steven Notley, Marc Turnage and Brian Becker (Leiden, Brill), pp. 41-51

Sanders, E. P., 1985. Jesus and Judaism (London, SCM Press)

-1992. Judaism: Practice and Belief 63 BCE - 66 CE (London, SCM)

Sankamo, Juho, 2012a. Jesus and the Gentiles (Turku, Åbo Akademis förlag)

-2012b. 'Josephus and Israel's universal role in the Eschaton' in Voces Clamantium in Deserto: Essays in Honor of Kari Syreeni, ed. Sven-Olav Back, and Matti Kankaanniemi (Åbo Akademi University), pp. 293-308

Stegemann, Wolfgang, 2011. 'Background III: the social and political climate in which Jesus of Nazareth preached' in Handbook for the Study of the Historical Jesus, vol. 3, ed. Tom Holmén, and Stanley E. Porter (Leiden, Brill)

Tan, Kim Huat, 1997. The Zion Traditions and the Aims of Jesus (Cambridge University Press)

Tatum, Barnes W., 1998. 'Jesus' so-called triumphal entry', Forum: A Journal of the Foundations and Facets of Western Culture, New Series 1, pp. 129-43

Witherington III, Ben, 1990. The Christology of Jesus (Minneapolis, Fortress Press) 